\title{
Reformulasi Tindak Pidana Perzinahan dalam Sistem Hukum Pidana Indonesia
}

\author{
Pahrur Rizal \\ Mahasiswa Program Studi Magister Ilmu Hukum Universitas Mataram \\ Email: rizalpahrur@gmail.com
}

\begin{abstract}
ABSTRAK
Perzinahan merupakan perbuatan yang dapat menimbulkan terganggunya keseimbangan kepentingan di dalam kehidupan bermasyarakat. Tindak pidana perzinahan sudah diatur dalam KUHP, namun tidak dapat mengakomodir nilai-nilai yang hidup. Dalam pasal 284 hanya mengatur zina yang dilakukan oleh sesorang yang masih dalam ikatan perkawinan. Rumusan KUHP tentang zina tersebut berbeda dengan norma yang hidup, yang menganggap zina adalah perbuatan bersetubuh yang dilakukan oleh laki-laki dengan perempuan yang tidak berada dalam ikatan perkawinan. Kemudian, metode penelitian menggunakan hukum normatif. Selanjutnya penelitian menggunakan pendekatan perundang-undangan dan pendekatan konseptual. Data diolah dengan metode penemuan hukum, yakni dengan menggali hukum yang hidup dalam masyarakat. Kemudian dianalisa menggunakan berpikir deduktif. Hasil penelitian menyimpulkan bahwa penerapan hukum pidana mengenai perzinahan dapat diterapkan dengan baik jika dalam melakukan kebijakan selalu mempertimbangkan berbagai kepentingan hukum yang hidup dalam masyarakat. Dengan demikian, memperbaharui hukum pidana dapat dilakukan dengan mengintegrasi berbagai nilai kultural yang hidup dalam masyarakat.
\end{abstract}

Kata kunci: Perzinahan (Delik Kesusilaan), Perkawinan dan Norma-Norma

\section{ABSTRACT}

Sex is a act that can make disturbing of importance balance in living society. Sex of criminal act have arranged in law dictionary of Indonesia, but isn't fill moral values alive. In 284 KUHP section just arrange sex who to do by some one of still bunch of marriage. The consept in KUHP about sex is different with the living norm in Indonesia society that assumption of sex is copulation by the men or women who isn't bunch of marriage. The use of method is research of legal formal. Subsequently, the research use law approach and concept approach. The result to the processed use invention of law, it mean examine living law in Indonesia society. Then, analyzed and concluded by deductive think. The resulting of research conclude that application of criminal law about morality act (sex) can be applied very well if always to consider values of law or norms that living in society. There for, repair Indonesia criminal law can to do by integrate all culture value that grow in Indonesia society.

Key words: Sex (Morality Act), Marriage and Norms 


\section{A. PENDAHULUAN}

Dalam kehidupan setiap masyarakat terdapat suatu peradaban yang menggambarkan keanekaragaman dalam masyarakat tertentu, yang memungkinkan akan potensi timbulnya suatu konflik, yang dengan otomatis melahirkan hukum untuk menawarkan penyelesaiannya pula. ${ }^{1}$ Mengatur hubungan hukum pada masyarakat, dibutuhkan suatu peraturan yang mempunyai tujuan luhur yang jelas yaitu menciptakan kepastian hukum dan mempertahankan nilai keadilan. Sehingga, masyarakat menghendaki adanya ketentuan peraturan yang memberikan sanksi-sanksi atau hukuman jelas bagi yang melanggar, Seperti halnya hukum pidana Indonesia yang sudah dikodifikasi. Sekalipun telah terkodifikasi, hukum pidana tersebut tidaklah dapat statis (kaku), karena Hukum pidana harus menyesuaikan diri dengan nilai hukum yang hidup dalam masyarakat, karena bersentuhan langsung dengan hajat hidup orang banyak dan berlaku secara umum, seperti yang diamanatkan dalam pasal 28 d UUD 1945 yaitu mewujudkan kepastian hukum yang berkeadilan, yang berbunyi; "Setiap orang berhak atas pengakuan, jaminan, perlindungan dan kepastian hukum yang adil serta perlakuan yang sama dihadapan hukum".

Hukum pidana merupakan salah satu aturan yang mengatur tingkah laku masyarakat yang berisi perintah dan larangan serta sanksi bagi yang melanggarnya. Sifat hukum pidana sebagai hukum publik bertujuan untuk melindungi kepentingan-kepentingan masyarakat sebagai suatu kolektivitas, Kepentingan masyarakat yang dimaksud yaitu jaminan keamanan, ketentraman dan ketertiban serta keadilan dalam bermasyarakat. ${ }^{3}$

Berhubung sifatnya sebagai hukum publik, perkembangan hukum pidana

\footnotetext{
${ }^{1}$ Pahrur Rizal. Makalah, Politik Hukum Pidana. Universitas Mataram. 2016. Hlm. 13

${ }^{2}$ Undang-Undang Dasar (UUD) 1945. Hlm. 22.

${ }^{3}$ Sudarto.Op. Cit. Hlm. 20
}

menjadi sorotan di tengah masyarakat, seperti yang dapat dilihat yakni bagaimana respon atau reaksi masyarakat terhadap rencana pembaharuan hukum pidana khususnya mengenai delik perzinahan dalam rumusan pasal $284 \mathrm{KUHP}$.

Mengenai Pasal tersebut, R. Soesilo menjelaskan bahwa yang dimaksud dengan zina adalah persetubuhan yang dilakukan oleh laki-laki atau perempuan yang telah kawin dengan perempuan atau laki-laki yang bukan isteri atau suaminya. ${ }^{4}$ Apabila merujuk ketentuan pasal 284, ketentuannya sangat terbatas yang nantinya akan memberikan kesempatan bagi para pelaku zina yang tidak terikat perkawinan.

Pasal 284 Kitab Undang Undang Hukum Pidana (KHUP) ruang lingkupnya mengenai zina adalah persetubuhan yang dilakukan oleh laki laki atau perempuan yang sudah kawin dengan perempuan atau laki laki yang bukan istri atau suaminya. Agar dapat termasuk dalam pasal ini maka persetubuhan itu harus diiasarkan atas suka sama suka, tidak boleh adanya pakasaan oleh salah satu pihak. Kemudian pasal ini juga melegalkan apabila seseorang, baik laki-laki maupun perempuan yang belum menikah untuk berbuat zina, yang dapat dijerat dengan pasal ini ialah orang yang sudah menikah saja, sedangkan untuk orang yang belum menikah tidak dapat dikenakan pasal ini. Selain itu pasal 284 KUHP adalah termasuk delik aduan absolut yang tidak memungkinkan perbuatan itu dipidana Jika tidak ada yang mengadukan dari pihak yang dirugikan (suami atau istri yang dikhianati pasangannya) dan, selama perkara itu belum diperiksa dimukan pengadilan, maka senantiasa pengaduan itu dapat ditarik kembali.

Sesungghnya ketentuan pasal perzinaan di atas bertentangan dengan jiwa dan roh Pancasila dan UUD 1945. Sebab, pada dasarnya adat dan agama-agama di

4 R. Soesilo, Kitab Undang-Undang Hukum Pidana (KUHP) Serta Komentar-Komentarnya Lengkap Pasal Demi Pasal, Politeia : Bogor. 1976. Hlm 209 
Indonesia melarang perzinahan. Hubungan hanya dibenarkan apabila melalui perkawinan yang sah. Jadi, jelas pasal 284 KUHP bertentangan dengan nilai Pancasila sebagai sumber dari segala sumber hukum, terutama Sila Ketuhanan Yang Maha Esa. Kemudian bertentangan dengan penjelasan Pasal 2 UU No. 12 Tahun 2011 tentang Pembentukan Peraturan Perundangundangan juga menempatkan Pancasila sebagai dasar, ideologi Negara sekaligus dasar filosofis Negara sehingga setiap materi muatan peraturan perundangundangan tidak boleh bertentangan dengan nilai-nilai yang terkandung dalam Pancasila.

Perzinahan dalam perspektif sudut pandang masyarakat, berbeda dengan perzinahan yang dirumuskan dalam pasal 284 KUHP di atas. Masyarakat memaknai perzinahan sebagai perbuatan yang dapat dilakukan oleh setiap orang, baik orang yang terikat perkawinan maupun tidak terikat perkawinan yang melakukan persetubuhan di luar hubungan yang sah. Pandangan masyarakat demikian ini, sejalan dengan pandangan Sahetapy yang mengemukakan perbuatan bersetubuh yang tidak sah berarti persetubuhan yang bukan saja dilakukan oleh laki-laki atau perempuan yang masih terikat perkawinan, tetapi juga persetubuhan yang dilakukan oleh pria dan wanita di mana keduanya belum terikat perkawinan, kendatipun sudah bertunangan. ${ }^{5}$ Sah disini harus ditafsirkan sah dalam ruang lingkup lembaga perkawinan, Sehingga zina meliputi persetubuhan yang dilakukan secara suka rela antara seorang yang belum menikah dengan seseorang yang belum menikah juga. Kemudian, Ny. As. Adamy juga mengemukakan tentang pengertian perzinahan yang dalam perumusannya mengatakan "perbuatan perzinahan yang cocok dengan masyarakat Indonesia yaitu terjadinya hubungan kelamin dengan lakilaki atau perempuan tanpa nikah lebih

5 Sahetapy dan B. Mardjno Reksodiputro. Parados dalam Kriminologi. Rajawali. Jakarta. 1989. Hlm 62 dahulu". ${ }^{6}$ Meskipun persetubuhan tersebut atas dasar suka sama suka, namun perbuatan bersetubuh itu tetap tidak sah. Menurut anggota masyarakat, karena persetubuhan yang sah hanya dilakukan dalam lembaga perkawinan. Pandanganpandangan atau anggapan-anggapan tersebut tidak terlepas dari nilai-nilai yang hidup dalam masyarakat baik itu nilai agama, nilai kesusilaan dan nilai kesopanan.

Perbedaan-perbadaan mengenai apa yang seharusnya dengan senyatanya tentang perzinahan yang disinggung di atas, menunjukkan bahwa ketentuan pasal 284 KUHP sudah tidak relevan dan tidak dapat dikatakan ideal sebagai sebuah produk hukum yang menjamin keamanan dan ketentraman dalam kehidupan masyarakatsebagai suatu kolektivitas, sebagaimana tujuan hukum yang di citacitakan. Pasal tersebut menimbulkan kesenjangan dalam masyarakat, karena substansi pasal tersebut tidak mampu mencerminkan dan mengakomodir nilainilai hukum yang hidup dalam masyarakat, permasalahan tersebut, dikarenakan adanya kekosongan hukum dalam aturan (KUHP) untuk mengatur perzinahan yang diharapkan oleh masyarakat.

Berdasarkan uraian di atas, penulis tertarik untuk meneliti nilai-nilai yang hidup dalam masyarakat (nilai kesusilaan, kesopanan dan agama) sebagai dasar untuk mereformulasikan perzinahan sebagai tindak pidana, dengan judul penelitian "reformulasi tindak pidana perzinahan dalam sistem hukum pidana Indonesia".
6 J.E. Sahetapi, Kapita Selekta Kriminologi, Alumni Bandung. Hlm. 188 C.S.T. Hlm. 15 


\section{B. PEMBAHASAN}

\section{Hukum yang Hidup dalam Masyarakat tentang Perzinahan Sebagai Delik Pidana}

\section{a. Pandangan Nilai Kesusilaan, Kesopanan dan Agama Tentang Perzinahan.}

Hukum merupakan suatu pedoman yang mengatur pola hidup manusia yang memiliki peranan penting dalam mencapai tujuan ketentraman hidup bagi masyarakat. Oleh karena itulah, hukum mengenal adanya adagium ibi societes ibi ius. ${ }^{7}$ Hal demikian sesuai dengan yang dikemukakan oleh Van Apeldoorn bahwa "tidaklah mungkin memberikan suatu definisi tentang apakah hukum itu, adalah sangat sulit untuk dibuat karena tidak mungkin untuk mengadakannya yang sesuai dengan kenyataan".

Pergaulan hidup sebagai masyarakat yang teratur adalah penjelmaan hukum, yaitu sesuatu dari hukum yang terlihat dari luar. Jadi hukum adalah masyarakat itu juga, hidup manusia sendiri, dilihat dari sudut yang tertentu, yakni sebagai pergaulan hidup yang teratur. ${ }^{9}$ Kemudian apa yang dibahas mengenai hukum diatas, sesuai dengan teori pluralisme hukum yang menurut Griffths, pluralisme hukum merupakan suatu kondisi yang terjadi diwilayah social manapun, dimana seluruh tindakan komunitas di wilayah tersebut diatur oleh lebih dari satu tertib hukum. ${ }^{10}$

Dalam pluralisme hukum yang memberlakukan bermacam-macam hukum, tidak mungkin ada unifikasi hukum. Karena unifikasi hukum itu merupakan suatu pemberlakuan satu macam hukum tertentu kepada semua rakyat di suatu Negara. Jika suatu hukum dinyatakan berlaku secara unifikasi, maka di Negara

\footnotetext{
${ }^{7}$ Loc. Cit. Hlm. 1

8 L.J. Van Apeldoorn. Pengantar Ilmu Hukum. Loc. Cit. Hlm. 23

${ }^{9}$ L.J. Van Apeldoorn. Loc. Cit. Hlm. 25

${ }^{10}$ Jhon Griffiths, Memahami Pluralisme Hukum, Sebuah Deskripsi Konseptual, dalam Pluralisme Hukum sebuah Pendekatan Interdisipliner, Loc. Cit. Hlm. 72
}

itu hanya berlaku satu macam hukum tertentu dan tidak berlaku bermacammacam hukum. ${ }^{11}$ Seperti yang diketahui bahwa dalam Negara, tidak hanya berlaku hukum yang diterapkan Negara, tetapi juga hukum yang hidup dalam masyarakat (norma adat, norma agama, norma kesusilaan). Pernyataan-pernyataan mengenai hukum di atas sesuai dengan konsep Negara hukum yang dianut Indonesia yaitu Pancasila.

Padmo Wahyono menelaah tentang Negara hukum Pancasila tersebut yang berpangkal dari asas kekeluargaan yang tercantum dalam UUD 1945. Dalam asas kekeluargaan yang diutamakan adalah "Rakyat Banyak", dengan tidak mengabaikan harkat dan martabat manusia. Sehingga Padmo Wahyono memahami hukum sebagai suatu alat atau wahana untuk menyelenggarakan kehidupan Negara atau ketertiban, dan menyelenggarakan kesejahteraan sosial. pengertian ini tercermin dalam rumusan penjelasan UUD 1945 yang bunyinya (UUD hanya memuat aturan-aturan pokok, hanya membuat garis-garis besar sebagai instruksi kepada pemerintah pusat dan penyelenggaraan Negara untuk menyelenggarakan kesejahteraan sosial dalam kehidupan bernegara $).^{12}$

Berbicara mengenai norma yang hidup dalam masyarakat Indonesia, maka kita akan dihadapkan dengan anggapananggapan, yang sedikit atau banyak mengikat perbuatan seseorang dalam masyarakat atau suatu kelompok dalam masyarakat. Anggapan-anggapan ini memberikan petunjuk bagaimana seseorang harus berbuat atau tidak harus berbuat. Anggapan-anggapan ini disebut norma atau kaidah. Jadi norma adalah anggapan-anggapan bagaimana seseorang harus berbuat atau tidak harus berbuat. ${ }^{13} \mathrm{Di}$ belakang anggapan-anggapan atau normanorma tersebut terdapat nilai-nilai yang

\footnotetext{
${ }^{11}$ Muhammad Bakri. Ibid. Hlm. 3

${ }^{12}$ H. Muhammad. Tahir Azhary. Ibid. Hlm. 95

${ }^{13}$ Sudarto. Loc. Cit. Hlm. 31
} 
merupakan dasar bagi norma. Nilai dapat diartikan sebagai ukuran yang disadari oleh suatu masyarakat atau golongan untuk menetapkan apa yang benar, yang baik dan sebagainya. Nilai mempengaruhi tingkah laku manusia. ${ }^{14}$ Nilai lebih abstrak daripada norma, system nilai suatu bangsa, golongan atau masyarakat pada setiap wilayah tidaklah sama.

Kehidupan dalam masyarakat yang sedikit banyak berjalan dengan tertib dan teratur ini didukung oleh adanya suatu norma (tatanan). Karena adanya norma inilah kehidupan menjadi tertib. Ketertiban yang didukung oleh adanya norma ini pada pengamatan lebih lanjut ternyata terdiri dari berbagai norma yang mempunyai sifat-sifat yang berlainan. Perbedaan yang terdapat pada norma-normanya dapat dilihat dari dua segi yaitu ideal dan kenyataan. $^{15}$ Apa yang dilihat sebagai suatu norma dalam masyarakat yaitu yang menciptakan hubungan-hubungan yang tetap dan teratur antara nggota-anggota masyarakat, sesungguhnya tidak merupakan suatu konsep yang tunggal. Yang kita lihat sebagai norma dari luar, pada hakikatnya di dalamnya terdiri dari suatu kompleks tatanan atau kita biasa menyebut tentang adanya suatu norma yang terdiri dari sub-sub norma. Sub-sub norma tersebut terdiri dari kesusilaan, kesopanan (adat) dan agama. Dengan demikian ketertiban yang terdapat dalam masyarakat itu didukung oleh ke tiga norma(tatanan) tersebut. ${ }^{16}$

Mungkin kita masih bisa melihat adanya bermacam-macam norma dalam masyarakat, lebih dari yang disebutkan diatas, tetapi disini mencukupkannya sampai pada ketiganya saja. Hal ini dilakukan oleh karena ketiganya melambangkan terjadinya tegangan yaitu antara ideal dan kenyataan sebagaimana yang akan dijelaskan dalam penulisan ini.

\footnotetext{
${ }^{14}$ Sudarto. Ibid. Hlm. 31

${ }^{15}$ Satjipto Rahardjo. Ilmu Hukum (cetakan ke-8). Bandung. PT. Citra Aditya Bakti. 2014. Hlm. 13

${ }^{16}$ Satjipto Rahardjo. Op. Cit. 14
}

Hubungan ketiga norma diatas, tidak bisa dipisahkan dalam pembentukkan norma hukum, karena pada pembentukan norma hukum, harus mempertimbangkan semua nilai-nilai yang hidup dalam menegakkan ketertiban dalam masyarakat itu sendiri. Norma hukum itu termasuk ke dalam golongan norma-norma yang lahir dari masyarakat, sehingga keanekaragaman norma seperti yang dibahas diatas dapat menjadi sebuah pertimbangan hukum dalam mewujudkan keadilan. Dalam perbedaan-perbedaan yang muncul antara norma agama, norma kesusilaan dan norma adat (kesopanan), yang mana perbedaanperbedaan ini merupakan bentuk pluralisme hukum juga, yang berlaku di Indonesia. Perbedaan-perbedaan tersebut, terdapat hubungan nilai-nilai diatara ketiga norma tersebut dalam mendorong pembentukkan hukum yang baik. ${ }^{17}$

Berdasarkan hubungan-hubungan norma-norma tersebut, penulis maka kesemua norma tersebut memberikan peraturan-peraturan terhadap manusia ataupun sekelompok manusia, karena hubungan antara berbagai golongan kaidah-kaidah atau norma-norma (norma agama, norma kesusilaan, norma kesopanan dan norma hukum). Sesungguhnya terdapat hubungan yang rapat antara berbagai norma-norma tersebut. Isi tiap-tiap norma menjalankan pengaruh yang kuat terhadap isi normanorma yang lain. Antara lain, pandangan norma agama, norma kesusilaan dan norma adat (kesopanan) terus menerus mempengaruhi norma hukum. Norma hukum untuk sebagian besar adalah kesusilaan positif yang diperlukan oleh pemerintah. ${ }^{18}$ Hal ini dapat menjadi dasar yang kuat dalam memberikan kepada hukum positif sesuatu kekekalan dan kekokohan azas-azas pokok. Kejahatankejahatan yang diuraikan dalam kitab undang-undang hukum pidana (KUHP), hampir semuanya perbuatan-perbuatan

${ }^{17}$ L.J. Van Apeldoorn. Op.Cit. Hlm. 5

${ }^{18}$ L.J. Van Apeldoorn. Ibid. Hlm. 8 
yang dicela oleh norma kesusilaan, norma kesopanan dan norma agama.

Mengenai hukum dalam masyarakat yang sudah dijelaskan, adalah merupakan bahan dan petunjuk bagi penulis untuk mengkaji problem-problem dalam masyarakat yang salah satunya terkait dengan "Perzinahan" seperti yang sudah juga disinggung di atas, yang kemudian akan penulis bahas lebih lanjut dalam karya ilmiah ini.

\section{b. Dasar Kriminalisasi Perzinahan Dalam Pembaharuan Hukum Pidana Indonesia.}

Perzinahan perlu mendapatkan kajian serius mengingat kerugian yang ditimbulkannya. Kerugian tersebut dapat terjadi pada negara, masyarakat maupun individu sehingga perlu diatasi. Oleh sebab itu, negara harus memberikan reaksi berupa larangan terhadap perbuatan itu serta memberikan sanksi bagi orang yang melanggarnya. Di samping itu dalam kenyataan sosial, reaksi sebagai upaya untuk menangani perzinahan tidak hanya diberikan oleh Negara, tetapi masyarakat dan individu yang merasa dirugikan rasa keadilannya, akan memberikan reaksi pula. Aturan pidana mengenai perzinahan yang kurang layak sering menjadi obyek ketidakpuasan masyarakat yang akhirnya menumbuhkan reaksi sosial.

Berkaitan dengan hal tersebut, penulis beranggapan bahwa akan selalu terjadi rasa ketidakpuasan dari masyarakat mengenai perilaku-perilaku menyimpang terutama dalam lingkup kesusilaan (perzinahan) seperti yang disebut di atas, jika perilaku-perilaku yang menyimpang dari norma-norma masyarakat tersebut, belum mendapatkan tempat semestinya dalam hukum pidana.

Para penegak hukum maupun ahli hukum banyak yang menyetujui delik perzinahan harus diatur sebagai suatu delik dalam hukum pidana, namun dengan tetap berdasarkan pada beberapa peraturan perundang-undangan yang mengakui keberadaan hukum tidak tertulis dan pernyataan-pernyataan hasil seminar atau simposium. ${ }^{19}$

Hal demikian sesuai dengan pandangan Sudarto yaitu, bahwa apabila hukum pidana itu digunakan untuk mengatasi permasalahan sosial tersebut, harus dipertimbangkan secara matang, karena hukum pidana itu mempunyai fungsi subsidier. Artinya baru digunakan apabila upaya-upaya lain diperkirakan kurang memberikan hasil yang memuaskan. Jika hukum pidana tetap dilibatkan untuk mengatasi permasalahan sosial tersebut (zina), maka hendaknya dilihat dalam hubungan keseluruhan kebijakan kriminal. ${ }^{20}$

Mengenai pemahaman sifat delik terhadap perzinahan, Barda Nawawi Arief memberikan pandangan sebagai berikut: ${ }^{21}$

a. Konsep nilai dan kepentingan yang melatarbelakangi sifat dan hakikat perzinahan.

Delik perzinahan merupakan salah satu delik kesusilaan yang erat kaitannya dengan kesucian lembaga perkawinan. Sehingga masalah sentralnya terletak pada pandangan masyarakat mengenai kesusilaan dan kesucian lembaga perkawinan. Pandangan barat yang melatarbelakangi WvS berbeda dengan pandangan masyarakat Indonesia mengenai perzinahan dan perkawinan. Perkawinan dalam pandangan masyarakat terkait pula dengan nilainilai dan kepentingan masyarakat. Sehingga tidak bijaksana apabila delik perzinahan tetap dijadikan delik aduan absolut.

${ }^{19}$ Muladi. Proyeksi Hukum Pidana Materiil di Indonesia di Masa Mendatang, Op. Cit. Hlm. 16

${ }^{20}$ Sudarto. Hukum dan Hukum Pidana. Op. Cit. Hlm. 104.

${ }^{21}$ Barda nawawi arief, kebijakan legislatif dalam penanggulangan kejahatan dengan pidana penjara, (cetakan kedua), (semarang, badan penerbit universitas diponegoro, 1996). Hlm. 41 
b. Aspek tujuan dari kebijakan kriminal (criminal policy).

Ditetapkannya suatu delik sebagai delik biasa merupakan sarana untuk mencapai tujuan-tujuan tertentu. Salah satu tujuannya adalah pencegahan, jika dengan ditetapkannya delik perzinahan sebagai delik aduan absolut, prevensinya lemah karena memberi peluang dan dasar legitimasi kepada seseorang untuk merasa bebas melakukan perzinahan. Hal ini justru menjadi faktor kriminogen.

c. Aspek kesusilaan nasional, faktor kriminogen dan dampak negatif lainnya dari perzinahan.

Tujuan politik kriminal dengan dilarangnya perzinahan adalah kesucian lembaga perkawinan dan pengaruh-pengaruh negatif sertaakibat buruk yang ditimbulkan perbuatan zina, adapun akibat perzinaan antara lain: $\left.{ }^{22} 1\right)$. Menghancurkan masa depan anak. Anak yang dihasilkan dari hubungan gelap (perzinaan) akan menghadapi masa kanak-kanaknya dengan tidak bahagia karena ia tidak memiliki identitas ayah yang jelas, 2). Merusak keturunan yang sah bila perzinaan menghasilkan seorang anak atau lebih. Keturunan yang sah menurut Islam adalah anak yang dilahirkan dari pernikahan yang sah. Bila hubungan gelap itu dilakukan dengan dua atau lebih laki-laki, maka akan mengaburkan hubungan nasab atau keturunan kepada bapak yang sebenarnya, 3). Mendorong perbuatan dosa besar yang lain, seperti menggugurkan kandungan, membunuh wanita yang telah hamil karena perzinaan, atau bunuh diri karena menanggung rasa malu telah berzina, 4). Menimbulkan berbagai jenis penyakit kelamin seperti, misalnya AIDS, bila perzinaan dilakukan dengan berganti-ganti pasangan. Walaupun

${ }^{22}$ Jhon Rawl. Op. Cit. Hlm. 41 saat ini telah ada alat pengaman hubungan cekcual, namun hal tersebut tidak menjamin bebas tertular penyakit cekcual menular.

d. Aspek kepentingan individu dan alternatif teknis perumusan delik.

Adanya perbuatan zina mengakibatkan kerugian individu bagi pihak yang terkena skandal perzinahan. Namun hal ini pun perlu dipertimbangkan dengan kepentingan umum yang turut dirugikan. Sehingga perlu dipertimbangkan secara proporsional antara kepentingan individu dengan kepentingan umum. Apabila ada dua kepentingan yang sama-sama kuat dan mendasar maka sepantasnya kedua kepentingan itu diperhatikan. $^{23}$

e. Kemudian mengenai sifat delik perzinahan di atas, penulis menambahkan dalam memberikan pertimbangan membenarkan perzinahan sebagai delik, yaitu dari aspek agama (islam, hindu dan Kristen). Perzinahan ini dalam tinjauan agama islam adalah perbuatan yang sangat dilarang dan sangat dilaknat oleh sayari'at islam, hal ini sebagaimana yang disebutkan dalam firman Allah SWT dalam kitab suci Alqur'an surat Al-Isra' (17) ayat 32 yang berbunyi;, ("Dan jangan kamu mendekati zina, sesungguhnya zina itu adalah perbuatan yang keji dan jalan yang buruk").

Menurut Durkheim, maka dasar hukum ini adalah suatu solidaritas sosial yang disebut solidaritas mekanik. Solidaritas jenis ini ditimbulkan dari kesamaan yang mengaitkan individu dengan masyarakat. Di dalam masyarakat ini ada kesamaan diantara para anggotanya

\footnotetext{
${ }^{23}$ Barda Nawawi Arief. Op. Cit. Hlm. 317.

${ }^{24}$ Q.S. Al Isra' (17) ayat 32. Dalam Yuana Nurshiyam (Tesis). Kebijakan Kriminalisasi Kumpul Kebo Dalam Pembaharuan Hukum Pidana Indonesia (Tesis). Universitas Deponegoro. Semarang. 2004. Hlm. 8
} 
mengenai

kebutuhan-kebutuhan

perikelakuan, kepercayaan dan sikap.

Perasaan kesamaan ini tidak hanya menarik para anggota masyarakat menjadi satu, melainkan juga menjadi landasan berdirinya masyarakatnya. Dengan demikian, maka serangan terhadap kepentingan masyarakat dihadapi dengan kesadaran bersama pula, yang mempunyai pola penindakan terhadap kejahatan. Dengan kata-kata Durkheim sendiri; di dalam kejadian-kejadian yang timbul dalam masyarakat, maka kekuasaan yang diserang oleh kejahatan itu dan yang menindaknya adalah sama. Ia merupakan hasil dari kesamaan sosial dan kesamaan ini menimbulkan efek dipertahankannya kohesi sosial yang lahir dari kesamaan ini. Kekuasaan inilah yang dilindungi hukum pidana terhadapa segala hal-hal yang melemahkan, baik dengan cara menuntut dari kita masing-masing minimum suatu kesamaan, tanpa hal mana seseorang akan merupakan bahaya bagi kesatuan dari kehidupan sosial, maupun dengan cara memaksa kita untuk menghormati lambang yang mengekspresikan dan menyarikan kesamaan ini pada saat bersamaan juga memberikan perlindungan kepada mereka. $^{25}$ Dari sinilah hukum terutama hukum pidana diharapkan sangat memegang peranan penting, sehingga perlu hukum yang melindungi dan menegakkan norma yang didalamnya terdapat nilai agama, susila dan kesopanan (adat). Sudikno Mertokusumo mengatakan bahwa kaidah hukum itu melindungi lebih lanjut kepentingan-kepentingan manusia yang telah mendapatkan perlindungan dari kaidah keagamaan, kaidah kesusilaan dan kaidah kesopanan. Disamping itu melindungi kepentingan manusia yang belum mendapatkan perlindungan dalam ketiga kaidah tersebut. ${ }^{26}$ Sehubungan dengan hal-hal tersebut diatas, maka pada prinsipnya hukum yang hidup (adat) di Indonesia menganggap perbuatan zina

\footnotetext{
${ }^{25}$ Satjipto Rahardjo. Ibid. Hlm. 104

${ }^{26}$ Sudarto. Hukum Pidana Dan Perkembangan Masyarakat. Sinar Baru. Bandung. Hlm. 53
}

merupakan perbuatan yang menentang kepentingan hukum masyarakat, dan ancaman hukumnya sangat berat.

Dalam pembaharuan hukum pidana memang harus memperhatikan nilai-nilai yang hidup dalam masyarakat dan asasasas hukum yang ada, menurut Roeslan Saleh aturan-aturan hukum yang terjadi oleh karena pembentuk undang-undang dalam membentuk aturan hukum atau hakim dalam keputusannya menimbangnimbang berbagai asas hukum yang satu dengan yang lainnya. Selain itu pula pembentukan hukum secara nasional harus menimbang berbagai aspek, terlebih bangsa Indonesia merupakan bangsa yang majemuk dalam hukum adat, sehingga ketentuan dalil-dalil kesusilaan khususnya yang menyangkut perzinahan dalam hukum pidana adat yang satu dengan yang lainnya berbeda, untuk itu harus dicari karakteristik guna membentuk hukum pidana nasional. ${ }^{27}$ Hal demikian dengan teori kebijakan hukum pidana yang penulis gunakan dalam karya ilmiah ini sangat cocok dalam memberikan arah penentuan hukum pidana, yang mana dalam toeri ini dikemukakan oleh Satjipto Rahardjo kebijakan hukum pidana adalah aktifitas memilih dan cara yang hendak dipakai untuk mencapai suatu tujuan sosial dan hukum tertentu dalam masyarakat. Sudarto mendifinisikan kebijakan hukum pidana adalah; ${ }^{28}$ (a). Usaha untuk mewujudkan peraturan-peraturan pidana yang baik sesuai dengan keadaan dan situasi pada suatu saat, (b). Kebijakan dari Negara melalui badan-badan Negara yang berwenang untuk menetapkan peraturanperaturan pidana yang dikehendaki yang diperkirakan akan dipergunakan untuk mengekspresikan apa yang terkandung dalam masyarakat dan untuk mencapai apa yang dicita-citakan.

Menurut Barda Nawawi Arief, usaha dan kebijakan untuk membuat peraturan

\footnotetext{
${ }^{27}$ Roeslan Saleh. Op. Cit. Hlm. 5

28 Sudarto. Hukum Pidana dan Perkembangan Masyarakat, (Bandung Sinar Baru, 1983), hlm. 20
} 
hukum pidana yang baik, pada hakikatnya adalah tidak dapat dipisahkan dari tujuan penanggulangan kejahatan. Jadi kebijakan hukum pidana juga merupakan bagian dari politik criminal, oleh karena itu kebijakan hukum pidana identik dengan pengertian kebijakan penanggulangan kejahatan dengan hukum pidana yang merupakan bagian dari penegakan hukum, khususnya penegakan hukum pidana, sehingga juga merupakan bagian dari kebijakan penegakan hukum pidana. Disamping itu, usaha penanggulangan kejahatan lewat pembuatan undang-undang hukum pidana pada hakikatnya juga merupakan bagian integral dari usaha perlindungan masyarakat dan usaha mencapai kesejahteraan masyarakat, oleh karena itu wajar apabila kebijakan hukum pidana juga merupakan bagian integral dari kebijakan sosial. $^{29}$

Berkenaan dengan pembaharuan hukum pidana, maka kebijakan kriminalisasi merupakan suatu kebijakan dalam menetapkan suatu perbuatan yang semula bukan merupakan tindak pidana menjadi suatu tindak pidana. Hakikatnya kebijakan kriminal merupakan bagian dari kebijakan kriminal yang menggunakan sarana hukum pidana. Dan oleh sebab itu kebijakan kriminal termasuk bagian dari kebijakan hukum pidana. ${ }^{30}$

\section{Soetandyo}

Wignjosubroto berpendapat bahwa Kriminalisasi ialah "suatu pernyataan bahwa suatu perbuatan itu harus dibilang sebagai perbuatan pidana", judgements and decision demikian itu, selalu dikonsepkan sebagai hasil-hasil formal yang berlangsung dan atau lewat lembaga-lembaga politik dan atau pemerintah dengan hasil akhirnya berupa produk perundang-undangan tepatnya perundang-undangan hukum pidana. $^{31}$ Kebijakan kriminal dapat

\footnotetext{
29 Barda Nawawi, Bunga Rampai Kebijakan Hukum Pidana (Perkembangan Penyusunan Konsep KUHP Baru ), Kencana, Jakarta, 2008. Hlm. 31

${ }^{30}$ Barda Nawawi. Ibid. Hlm. 126 Soetandyo Wignjosubroto. Kebijakan kriminalisasi dan dekriminalisasi dalam pembahaharuan
}

dikatakan sebagai kebijakan proses penyusunan perbuatan yang semula bukan tindak pidana menjadi perbuatan yang diancam pidana. Kebijakan kriminal ini pada dasarnya berupa penekan pada upaya pemilihan (baik perbuatan maupun sanksinya) untuk mewujudkan suatu perundang-undangan yang baik. Peraturan perundang-undangan yang baik berarti sesuai dengan keadaan dan situasi pada waktu (baik sekarang maupun yang akan datang) sehingga dapat menampung rasa keadilan bagi masyarakat.

Ditinjau dari aspek pokok tujuan pemidanaan, sebagaimana tujuan Negara Indonesia yang tercantum dalam pembukaan undang-undang dasar 1945 alenia ke empat yaitu untuk membentuk suatu pemerintahan Negara Indonesia yang melindungi segenap bangsa Indonesia dan untuk memajukan kesejahteraan umum berdasarkan Pancasila, adalah disamping sebagai landasan kebijakan umum juga sebagai landasan kriminal melalui sarana sanksi hukum pidana. Dengan demikian kebijakan kriminalisasi perzinahan harus berorientasi pada tujuan Negara tersebut. ${ }^{32}$

Adapun beberapa tujuan umum dalam berbagai sudut pandang yaitu; ${ }^{33}$ (a). Dilihat dari sudut perlunya perlindungan masyarakat, kriminalisasi terhadap perzinahan akan memberikan perlindungan terhadap masyarakat, yang menurut $\mathrm{J}$. Andenaes bahwa salah satu pengaruh prevensi umum dari pidana adalah untuk membuat larangan-larangan moral, sehingga mendorong untuk melakukan perbuatan patuh pada hukum, (b). Dilihat dari sudut perlunya perlindungan masyarakat terhadap sikap amoral pelaku, maka dengan memberikan pidana akan dapat memberikan pendidikan bagi sipelaku. Dengan demikian sipelaku akan

\footnotetext{
hukum pidana Indonesia. Dalam Dalam Yuana Nurshiyam (Tesis). Kebijakan Kriminalisasi Kumpul Kebo Dalam Pembaharuan Hukum Pidana Indonesia (Tesis). Universitas Deponegoro. Semarang. 2004. Hlm. 20

${ }^{32}$ Yuana Nurshiyam (Tesis). Op. Cit. Hlm. 66

33 Yuana Nurshiyam. Kebijakan Kriminalisasi Kumpul Kebo. Ibid. Hlm. 88
} 
dapat merubah sikapnya agar sesuai dengan hukum dan agama atau yang disebut prevensi special, (c). Dilihat dari perlunya perlindungan masyarakat untuk mempertahankan keseimbangan atau keselarasan berbagai kepentingan dan nilai-nilai yang terganggu oleh adanya kejahatan, maka sering pula dikatakan bahwa tujuan pemidanaan adalah untuk memelihara atau memulihkan keseimbangan masyarakat. Tujuan serupa ini mengandung makna pemidanaan menurut hukum adat. Dengan kriminalisasi tersebut akan menyeimbangkan nilai-nilai yang hidup dalam masyarakat yang diakibatkan oleh perbuatan amoral atau perbuatan tercela, sehingga akan mendatangkan kedamaian dalam masyarakat.

\section{Kebijakan Hukum Pidana Tentang Perzinahan.}

\section{a. Pembaharuan Hukum Pidana Dalam Kebijakan Formulasi, Aplikasi dan Eksekusi Mengenai Perzinahan}

Kebijakan merupakan sarana untuk mencapai tujuan, menyebutkan kebijakan sebagai program yang diproyeksikan atau diwujudkan berkenaan dengan tujuan, nilai dan praktek. Disamping itu juga kebijakan diartikan sebagai rangkaian, konsep dan asas yang menjadi garis besar pelaksanaan suatu pekerjaan dan cara bertindak. Kebijakan hukum pidana tidak dapat dipisahkan dari sistem hukum pidana. Dalam hal ini, Marc Ancel menyatakan bahwa setiap masyarakat yang terorganisir memiliki sistem hukum yang terdiri dari peraturan-peraturan hukum pidana beserta sanksinya, suatu prosedur hukum pidana dan suatu mekanisme pelaksanaan pidana. $^{34}$

Kebijakan hukum pidana berkaitan dengan proses penegakan hukum (pidana) secara menyeluruh. Oleh sebab itu, kebijakan hukum pidana diarahkan pada konkretisasi, operasionalisasi dan

${ }^{34}$ Muladi dan Barda Nawawi Arief. Ibid. Hlm. funsionalisasi hukum pidana material (substansial), hukum pidana formal (hukum acara pidana) dan hukum pelaksanaan pidana. Selanjutnya kebijakan hukum pidana dapat dikaitkan dengan tindakan-tindakan: ${ }^{35} 1$ ). Bagaimana upaya pemerintah untuk menanggulangi kejahatan dengan hukum pidana; 2). Bagaimana merumuskan hukum pidana agar sesuai dengan kondisi masyarakat; 3). Bagaimana kebijakan pemerintah untuk mengatur masyarakat dengan hukum pidana; 4). Bagaimana menggunakan hukum pidana untuk mengatur masyarakat dalam rangka mencapai tujuan yang lebih besar.

Penggunaan hukum pidana dalam mengatur masyarakat pada hakekatnya merupakan bagian dari suatu langkah kebijakan seperti yang disinggung di atas. Operasionalisasi kebijakan hukum pidana dengan sarana penal dapat dilakukan melalui proses yang terdiri atas tiga tahap, yakni $:^{36} 1$ ). Tahap formulasi (kebijakan legislatif); 2). Tahap aplikasi (kebijakan yudikatif/yudisial); 3). Tahap eksekusi (kebijakan eksekutif atau administratif).

Berdasarkan hal di atas, kebijakan hukum pidana terkandung di dalamnya tiga kekuasaan atau kewenangan, yaitu kekuasaan legislatif atau formulatif berwenang dalam hal menetapkan atau merumuskan perbuatan apa yang dapat dipidana yang berorientasi pada permasalahan pokok dalam hukum pidana meliputi perbuatan yang bersifat melawan hukum, pertanggungjawaban pidana dan sanksi apa yang dapat dikenakan oleh pembuat undang-undang. Tahap aplikasi merupakan kekuasaan dalam hal menerapkan hukum pidana oleh aparat penegak hukum atau pengadilan, dan tahapan eksekutif atau administratif dalam melaksanakan hukum pidana oleh aparat pelaksana atau eksekusi pidana. Dilihat dari perspektif hukum pidana, maka

\footnotetext{
${ }^{35}$ Muladi dan Barda Nawawi Arief. Ibid. Hlm.
}

${ }^{36} \mathrm{Http}: / /$ masrudim.blogspot.co.id 
kebijakan formulasi harus memperhatikan harmonisasi internal dengan sistem hukum pidana atau aturan pemidanaan umum yang berlaku saat ini. Tidaklah dapat dikatakan terjadi harmonisasi atau sinkronisasi apabila kebijakan formulasi berada diluar sistem hukum pidana yang berlaku saat ini. Kebijakan formulasi merupakan tahapan yang paling stategis dari penal policy karena pada tahapan tersebut legislatif berwenang dalam hal menetapkan atau merumuskan perbuatan apa yang dapat dipidana yang berorientasi pada permasalahan pokok hukum pidana meliputi perbuatan yang bersifat melawan hukum, kesalahan, pertanggung jawaban pidana dan sanksi apa yang dapat dikenakan. Oleh karena itu, upaya penanggulangan kejahatan bukan hanya tugas aparat penegak hukum tetapi juga tugas aparat pembuat undang-undang.

Perencanaan (planning) pada tahapan formulasi pada intinya, menurut Nils Jareborg mencakup tiga masalah pokok struktur hukum pidana, yaitu masalah: ${ }^{38}$ (a). Perumusan tindak pidana atau kriminalisasi dan pidana yang diancamkan (criminalisation and

threatened punishment); (b). Pemidanaan (adjudication of punishment sentencing); (c). Pelaksanaan pidana (execution of punishment).

Pada tahap selanjutnya, hukum yang telah dipilih sebagai sarana untuk mengatur kehidupan bermasyarakat, berbangsa dan bernegara yang berwujud peraturan perundang-undangan melalui aparatur negara, maka perlu ditindak lanjuti usaha pelaksanaan hukum itu secara baik sesuai dengan ketentuan yang telah ditetapkan. Pada tahap ini termasuk ke dalam bidang penegakan hukum, dalam hal ini perlu diperhatikan komponen-komponen yang terdapat dalam sistem hukum yaitu struktur, substansi dan kultur.
Sebagai suatu proses yang bersifat sistemik, maka penegakan hukum pidana menampakkan diri sebagai penerapan hukum pidana (criminal law application) yang melibatkan berbagai sub-sistem struktural berupa aparat kepolisian, kejaksaan, pengadilan dan pemasyarakatan. Termasuk di dalamnya tentu saja lembaga penasehat hukum. Dalam hal ini penerapan hukum haruslah dipandang dari 3 dimensi, yaitu : ${ }^{39}$ (a). Penerapan hukum dipandang sebagai sistem normatif (normative system) yaitu penerapan keseluruhan aturan hukum yang menggambarkan nilai-nilai sosial yang di dukung oleh sanksi pidana; (b). Penerapan hukum dipandang sebagai sistem administratif (administrative system) yang mencakup interaksi antara pelbagai aparatur penegak hukum yang merupakan sub-sistem peradilan di atas; (c). Penerapan hukum pidana merupakan sistem sosial (social system), dalam arti bahwa dalam mendefinisikan tindak pidana harus pula diperhitungkan pelbagai perspektif pemikiran yang ada dalam lapisan masyarakat. Sehubungan dengan pelbagai dimensi di atas dapat dikatakan bahwa sebenarnya hasil penerapan hukum pidana harus menggambarkan keseluruhan hasil interaksi antara hukum, praktek administratif dan pelaku sosial.

\section{b. Konsep Perzinahan Yang Sesuai Dengan Nilai-Nilai Masyarakat Indonesia.}

Konsep perzinahan sesungguhnya sudah diatur dalam KUHP yang berlaku di Indonesia. Namun dalam kenyataan masyarakat, konsep tersebut tidak dapak mengakomodir dan tidak relefan dengan nilai-nilai yang sudah dijelaskan pada bab sebelumnya. Karena konsep yang terdapat dalam pasal 284 KUHP sangat terbatas ruang lingkupnya.

Adapun beberapa pandanganpandangan terhadap perzinahan ditinjau

\footnotetext{
${ }^{37}$ Barda Nawawi Arief. Op. Cit. Hlm. 80

${ }^{38}$ Nils Jareborg dalam Barda Nawawi Arif, Ibid.
}

${ }^{39}$ Barda Nawawi Arief. Hlm. 168 
dari pancasila sebagai intisari nilai agama dan nilai adat (kesopanan) di Indonesia.

1) Perspektif Agama

Perspektif agama terhadap perzinahan dapat dikemukakan sebagai berikut: a). Menurut hukum pidana Islam, tidak mempersoalkan apakah pelaku-pelakunya telah diikat perkawinan dengan orang lain atau belum. Setiap persetubuhan di luar perkawinan yang sah adalah zina. Adapun persetubuhan yang dilakukan dengan paksaan atau persetubuhan dengan wanita dalam keadaan tidak berdaya atau pingsan hanya merupakan alasan penghapus pidana bagi wanita yang menjadi korban. ${ }^{40}$ Bagi pria yang melakukan perbuatan-perbuatan itu tetap dikategorikan sebagai pelaku zina, b). Perzinahan dalam tinjauan Islam adalah lebih luas dari pada pembatasan-pembatasan dalam KUHP tersebut. Islam tidak mempersoalkan dengan siapa persetubuhan itu dilakukan. Apabila persetubuhan ini dilakukan oleh orang yang telah menikah maka pelakunya disebut pelaku muhsan, dan apabila persetubuhan ini dilakukan oleh orang yang belum menikah maka pelakunya disebut pelaku gairu muhsan, c). Menurut Islam, ancaman pidana disesuaikan dengan pelaku perzinahan. Jika pelaku zina itu muhsan atau telah menikah maka ancaman pidananya adalah rajam (stoning to death). Namun jika perzinahan itu dilakukan oleh orang yang belum menikah (gairu muhsan) maka ancaman pidananya adalah dicambuk atau didera sebanyak delapan puluh kali.

$\begin{aligned} & \text { Ketentuan yang } \\ & \text { mengatur } \\ & \text { mengenai } \\ & \text { Hukuman (had) dapat } \\ & \text { dijatuhkan }\end{aligned}$ apabila ada pengakuan dari pelaku bahwa dia telah melakukan zina atau dari keterangan saksi. Karena menyangkut hidup dan matinya seseorang, keterangan saksi ini mempunyai persyaratan-persyaratan yang khusus, yaitu: ${ }^{41}$ a). jumlah saksi harus empat orang laki-laki atau apabila tidak ada orang laki-laki maka setiap orang laki-laki hanya dapat digantikan oleh dua orang wanita; b). saksi-saksi itu haruslah sudah baligh, berakal sehat dan bersikap adil; c). saksi-saksi itu harus beragama Islam; d). keempat orang saksi itu mengetahui peristiwa perzinahan secara mendetail.

Hukum pidana Islam tidak memandang zina sebagai delik aduan, tetapi dipandang sebagai dosa besar yang harus ditindak tanpa menunggu pengaduan dari orang-orang yang bersangkutan. Jika persyaratan saksisaksi telah terpenuhi maka qodli (hakim) dapat memutuskan perkara perzinahan itu. Saksi di sini tidak menutup kemungkinan dari suami atau isteri pelaku atau pun orang lain.

2) Perspektif Adat (kesopanan)

Perspektif norma adat terhadap perzinahan dapat dikemukakan sebagai berikut:

a) Menurut norma adat, perzinahan tidak hanya dilakukan oleh orang yang sudah kawin. Jadi baik sudah menikah maupun belum menikah jika melakukan persetubuhan di luar hubungan yang sah tetap dianggap sebagai perbuatan yang terlarang dan disebut juga sebagai zina. $^{42}$

b) Menurut norma adat, berat atau ringannya pidana tergantung dari hukum adat yang berlaku di lingkungan adat masingmasing. ${ }^{43}$ Adapun tindakan reaksi atau koreksi terhadap kejahatan dalam lingkungan masyarakat adat Indonesia dikenal tindakan-

\footnotetext{
${ }^{41}$ Sayyid Sabiq. Op. Cit. Hlm. 109-117.

${ }^{42}$ Hilman Hadikusuma. Op. Cit. Hlm. 88.

${ }^{43}$ I Made Widnyana.Op. Cit. Hlm. 44.
} 
tindakan sebagai berikut: 1). Penggantian kerugian materiel dalam berbagai rupa seperti paksaan untuk menikahi gadis yang telah dicemarkan, 2). Pembayaran uang adat kepada yang terkena, berupa benda sakti sebagi pengganti kerugian rohani, 3). selamatan (korban) untuk membersihkan masyarakat dari segala kotoran aib, 4). penutup malu atau permintaan maaf, 5). pengasingan dari masyarakat serta meletakkan orang di luar tata hukum, 6). hukuman badan.

Dalam norma adat, Setiap perbuatan atau kejadian yang bertentangan dengan kepatutan, kerukunan, ketertiban, keamanan, rasa keadilan dan kesadaran hukum masyarakat bersangkutan, baik hal itu akibat perbuatan seseorang maupun perbuatan penguasa sendiri, maka perbuatan atau kejadian itu dianggap sebagai delik adat. ${ }^{44}$ Oleh sebab itu dengan alasan manusia tidak akan mampu meramalkan masa yang akan datang, maka ketentuan-ketentuan dalam hukum adat tidak pasti dan bersifat terbuka untuk segala peristiwa atau perbuatan yang mungkin terjadi. Yang dijadikan ukuran utama menurut hukum adat adalah rasa keadilan dan kesadaran hukum masyarakat sesuai dengan perkembangan keadaan, waktu dan tempat. ${ }^{45}$

Dalam kehidupan masyarakat Indonesia yang dikenal dengan bangsa yang teguh memegang nilai-nilai keagamaan dan adat, maka tentunya akan memandang perzinahan sebagai perbuatan tabu atau kotor. ${ }^{46}$ Jadi secara umum, pemakaian kata zina dalam masyarakat Indonesia menunjuk pada suatu perbuatan bersetubuh di luar

\footnotetext{
${ }^{44}$ H. Hilman Hadikusuma. Op. Cit. Hlm. 10.

${ }^{45}$ H. Hilman Hadikusuma. Ibid. Hlm. 12

46 LPHN, Pengaruh Agama Terhadap Hukum Pidana. Dalam Yuana Nurshiyam (Tesis). Op. Cit. Hlm.

perkawinan yang sah atau dengan kata lain zina merupakan hubungan seksual antara laki-laki dan perempuan yang tidak didasari oleh suatu pernikahan.

Berdasarkan berbagai nilai-nilai sudut pandang mengenai perzinahan di atas, maka konsep perzinahan dalam pasal 284 KUHP harus dirubah atau direformulasikan. Munculnya suatu gagasan bahwa perzinahan harus direformulasikan konsepnya dalam peraturan perundang-undangan. Hal ini disebabkan terjadinya beberapa desakan dari masyarakat mengenai konsep perzinahan dalam mengembalikan moral dan rasa susila masyarakat.

3) Perzinahan dalam perspektif kesusilaan

Dalam perspektif ini perzinahan merupakan perbuatan yang bertentangan dengan hati nurani manusia yang membuat seseorang selalu merasa bersalah, dimana norma tersebut berakar dari suara hati manusia, yang mana bekerja atas dasar kesadaran setiap manusia terhadap sekelilingnya. Artinya setiap manusia dikaruniai Tuhan Yang Maha Esa sebuah organ yang mampu menjadi neraca pertimbangan yang setiap saat memberi pertimbangan atas apa yang diperbuatnya. Jika manusia melakukan kesalahan maka akan merasa bersalah dan penyesalan yang mendalam. Semakin sehat hati manusia, maka akan semakin efektif kehidupannya karena senantiasa memperoleh atau mendapatkan pertimbangan hati nurani yang sehat pula. ${ }^{47}$

Kesusilaan berpegangan pada ideal yang masih harus diwujudkan dalam masyarakat. Idealah yang merupakan tolok ukur norma kesusilaan ini untuk menilai tingkah laku anggota-anggota masyarakatnya. Dengan demikian, perbuatan yang bisa

${ }^{47}$ Ilham Bisri. Op. Cit. Hlm. 3 
diterima oleh norma tersebut hanyalah yang sesuai dengan yang idealnya tentang manusia. Selanjutnya kesusilaan dapat dijadikan ukuran dalam memutuskan apa yang akan diterima sebagai norma di situ. Tujuan norma kesusilaan penyempurnaan seseorang (walaupun juga menimbulkan akibat-akibat untuk hidup bersama, karena perbaikan manusia tentunya turut membantu tercapainya tata tertib masyarakat yang lebih baik). Kesusilaan memegang peranan utama, pada umumnya peraturan-peraturan hukum kita lakukan dengan sukarela karena ia merasa berwajib terhadap suara hati kita. Dalam menjalankan perintahperintahnya hukum mempunyai pegangan yang kuat dalam kesusilaan.

Dasar kekuatan susila dari hukum itu bisa beragam-ragam. Suatu kemungkinan ialah bahwa isi peraturan hukum berpatutan dengan keyakinan susila. Norma hukum tiada jarang terpaksa menjatuhkan vonis hukuman atas perbuatan-perbuatan yang ditimbulkan oleh alasan-alasannya yang dibenarkan oleh kesusilaan, dengan perkataan lain bahwa norma hukum harus menjatuhkan hukuman atau apa yang dibenarkan, bahkan sampai-sampai yang dituntut oleh norma kesusilaan. Dengan nilai kesusilaan diatas, sangat jelaslah bahwa perzinahan sangat dilarang keras dan dengan kuatnya dorongan dan kontribusi peranan kesusilaan untuk membenarkan perzinahan menjadi delik pidana dan menjadi delik biasa dalam hukum pidana. ${ }^{48}$

Berdasar pada pernyataan-pernyataan tentang zina di atas, maka zina adalah melakukan hubungan badan di luar nikah, baik yang salah satunya terikat tali perkawinan (zina muhsan, yaitu zina yang dilakukan oleh laki-laki atau perempuan yang bukan suami atau istrinya, yang

${ }^{48}$ Ilham Bisri. Op. Cit. Hlm. 4 sudah menikah dan salah satu atau keduanya masih terikat status perkawinan dengan orang lain), dan keduanya belum terikat perkawinan (zina ghairu muhshan, yaitu zina yang dilakukan oleh laki-laki atau perempuan yang belum pernah menikah atau masih perjaka atau gadis). Karena pada hakekatnya zina adalah terjadinya hubungan kelamin dengan lakilaki atau perempuan yang dilakukan di luar lembaga perkawinan.

Pendapat demikian sesui dengan yang dikemukakan Ny. As. Adamy bahwa "perbuatan perzinahan yang cocok dengan masyarakat Indonesia yaitu terjadinya hubungan kelamin dengan laki-laki atau perempuan tanpa nikah lebih dahulu".49 Meskipun persetubuhan tersebut atas dasar suka sama suka, namun perbuatan bersetubuh itu tetap tidak sah. Menurut anggota masyarakat, karena persetubuhan yang sah hanya dilakukan dalam lembaga perkawinan.

\section{PENUTUP}

\section{Simpulan}

a. Ditinjau dari perspektif hukum yang hidup dalam masyarakat (norma agama, norma kesusilaan dan norma kesopanan), Perzinahan dalam bentuk apapun dapat dijadikan suatu delik pidana. Hal demikian dikarenakan mengganggu keseimbangan dalam masyarakat, melanggar kesucian nilai-nilai sakral perkawinan serta bertentangan dengan nilai Pancasila yang merupakan sumber dan ideology bangsa. Perzinahan juga dapat mengakibatkan hal-hal yang sangat fatal baik bagi pelaku zina, moral generasi dan moral suatu bangsa.

b. Memperbaharui hukum pidana terkait perzinahan dalam upaya perlindungan masyarakat dan

49 J.E. Sahetapi, Kapita Selekta Kriminologi, Alumni Bandung. Hlm. 188 C.S.T. Hlm. 15 
untuk mencapai kesejahteraan masyarakat, dapat ditentukan secara integratif dari berbagai kepentingan hukum yang hidup dalam masyarakat Indonesia (nilai agama, susila dan kesopanan) melalui ruang lingkup kebijakan hukum pidana. Sehingga dalam pembaharuan tersebut menghasilkan produk-produk aturan yang merumuskan unsur perzinahan yang bersifat kultural yang berorientasi pada nilai-nilai kesusilaan nasional (NKN) yang telah disepakati bersama atau didasarkan pada nilai-nilai yang tumbuh dan berkembang dalam masyarakat.

\section{Rekomendasi}

a. Perlunya nilai-nilai yang hidup, baik itu nilai agama, kesusilaan dan kesopanan dalam masyarakat untuk diberikan tempat dan fungsi dalam menentukan suatu perbuatan apakah perlu untuk dikriminalisasikan atau tidak dan diselesaikan dengan caranya sendiri, sehingga dalam apa yang menjadi fungsi atas nilai-nilai itu tetap di akui dengan baik dan berjalan efektif sesuai porsinya.

b. Melakukan kebijakan hukum, beragam kultur hukum di Indonesia perlu di perhatikan dan dikembangkan, baik untuk keperluan ilmu maupun praktek. Dari segi praktek barangkali hal ini dapat dihubungkan dengan usaha untuk membuat norma-norma serta pranata hukum yang nantinya dapat bekerja dengan efektif. Dalam hubungan ini, legislatif maupun pemerintah ada baiknya untuk mempertimbangkan bahwa masyarakat Indonesia yang majemuk tata kulturnya, psikologinya dan sebagainya perlu diperhitungkan dengan sebaikbaiknya agar konsep peraturan- peraturan yang dibuat nantinya, dapat bekerja dengan efektif.

\section{DAFTAR PUSTAKA}

\section{Buku}

Agus Dwi Wahyu Nurcahyono. Penegakan Hukum Pidana Terhadap Tindak Pidana Perzinahan di Pengadilan Negeri Sragen. Universitas Muhammadiyah Surakarta.

Altidjo Alkostar dan M. Sholeh Amin. Pembaharuan Hukum Pidana Perspektif Politik Hukum Nasional. Rajawali. Jakarta. 1986.

Amiruddin dan H.Zainal Asikin. Pengantar Metode Penelitian Hukum, Jakarta, Rajawali Press, 2013.

Andi Hamza. Asas-Asas Hukum Pidana (edisi revisi 2008). PT. Rineka Cipta. Jakarta. 2008.

A.S.S Tambunan. Politik Hukum Berdasarkan UUD 1945, (Jakarta, Puporis, 2002).

Bambang Poernomo. Kapita Selekta Hukum Pidana. Liberty. Yogyakarta. 1988.

Barda Nawawi. Bunga Rampai Kebijakan Hukum Pidana (Perkembangan Penyusunan Konsep KUHP Baru ), Kencana, Jakarta, 2008.

Barda Nawawi Arief, Kebijakan Legislatif dalam Penanggulangan Kejahatan dengan Pidana Penjara, (cetakan kedua), Badan Penerbit Universitas Diponegoro, 1996.

B. Simandjuntak. Pengantar Kriminologi Dan Patologi Sosial. Tarsito. Bandung. 1981.

Departemen Pendidikan dan Kebudayaan. Kamus Besar 
Bahasa Indonesia, (Balai Pustaka, Jakarta, 1985).

Didik Sukriono. Pembaharuan Hukum Pemerintah Desa, Politik Hukum Pemerintah Desa di Indonesia. Setara Press. Malang. 2010.

Edi Soharto, Kebijakan Sosial Sebagai Kebijakan Publik, Alfabeta Bandung. 2007.

Eugen Ehrlich, dalam Ronny Hanitijo. Permasalahan Hukum Dalam Masyarakat. Alumni. Bandung. 1984.

H. Muhammad. Tahir Azhary. Negara Hukum (suatu studi tentang prinsip-prinsipnya dilihat dari segi hukum islam, implementasinya pada periode negara madinah dan masa kini). Jakarta. PT. kencana. 2015.

H.R. Otje Salman Soemadiningrat. Rekonseptualisasi Hukum Adat Kontemporer (telaah kritis terhadap hukum adat sebagai hukum yang hidup dalam masyarakat). PT. Alumni. Bandung. 2002.

I Dewa Made Suartha. Hukum Dan Sanksi Adat Perspektif Pembaharuian Hukum Pidana. Setara Press. Malang. 2015.

Ilham Bisri. System Hukum Indonesia (prinsip-prinsip dan implementasi hukum di Indonesia). PT. Raja Grafindo Persada. Jakarta. 2012.

J.E. Sahetapi, Kapita Selekta Kriminologi, Alumni Bandung. Hlm. 188 2C.S.T.

Jhon Griffiths, Memahami Pluralisme Hukum, Sebuah Deskripsi Konseptual, dalam Pluralisme Hukum sebuah Pendekatan Interdisipliner, penerjemah Andri Akbar, Jakarta: Huma, 2005).

Johnny Ibrahim, Teori \& Metodologi Penelitian Hukum Normatif,
Banyumedia Publishing, Malang, 2005.

Lawrence M. Friedman, System Hukum Perspektif Ilmu Social (A legal system A social science perspective). Diterjemahkan oleh M. Khozim. (Bandung: Nusa Media, 2009).

Leden Marpaung. Asas-Teori-Praktek Hukum Pidana. Sinar Grafika. Jakarta. 2009.

L.J. Van Apeldoorn. Pengantar Ilmu Hukum. PT. Pradnya Paramita. Jakarta. 2009.

Mochtar Kusumatmadja. Masyarakat Dan Pembangunan Hukum Nasional (Penelitian Hukum Dan Kriminologi Fakultas Hukum Universitas Padjadjaran). Bina Cipta. Bandung. 1986.

Moeljatno. Fungsi dan Tujuan Hukum Pidana Indonesia (RUU tentang asas-asas dan dasar-dasar pokok tata hukum Indonesia). PT. Bina Aksara. Jakarta.

Moeljatno. Kitab Undang-undang Hukum Pidana(KUHP), cet 28. Bumi Aksara. Jakarta 2009.

Moore. S.F. Law And Social Change; Keadilan Di Berbagai Ruangan Lembaga Peradilan, Penataan Masyarakat Secara Hukum Rakyat. Dalam Antropologi Hukum Sebuah Bunga Rampai, penyunting, T.O. Harmoni. Yayasan Obor Indonesia. Jakarta. 2003.

Muhammad Bakri. Unifikasi dalam pluralism hukum tanah di Indonesia (Rekonstruksi Konsep Unifikasi dalam UUPA). Kertha Patrika Vol.33 No. 1, Januari 2008.

Muladi dan Barda Nawawi Arief. TeoriTeori Dan Kebijakan Pidana. Alumni. Bandung. 1998. 
Paul Schiff Berman. Federalism And International Law Through The Lens Of Legal Pluralism, (Missouri Law Review, Volume 73, 2008).

Sahetapy dan B. Mardjno Reksodiputro. Parados dalam Kriminologi. Rajawali. Jakarta. 1989.

Satjipto Rahardjo. Ilmu Hukum (cetakan ke-8). Bandung. PT. Citra Aditya Bakti. 2014.

Satya Arinanto. Politik Pembangunan Hukum Nasional, dalam Jurnal Legislasi Indonesia.

Shidarta. Karakteristik Penalaran Hukum Dalam Konteks Keindonesiaan. CV. Utomo. Bandung. 2009.

Soeleman B Teneko. Hukum Adat Suatu Pengantar Awal Dan Prediksi Masa Mendatang. Eresco. Bandung. 1987.

Soerjono Soekanto. Pokok-Pokok Sosiologi Hukum. Rajawali Press. Jakarta. 1988.

Sudarto. Hukum Pidana dan Perkembangan Masyarakat. Bandung Sinar Baru, 1983.

Sunarjati Hartono. Dari Hukum Antar Golongan Ke Hukum Antar Adat. Alumni. Bandung. 1997.

Sunoto. Mengenal Filsafat Pancasila (edisi ke 3). PT. Menindita Offset. Yogyakarta. 1984.

Suratman \& Philips Dillah. Metode Penelitian Hukum. Alfabeta. Bandung, 2013.

Sutherland \& Cressey (disadur oleh Sudjono D). The Control of Crime Hukuman dalam Perkembangan Hukum Pidana. Tarsito. Bandung, 1974.

Teguh Prasetyo dan Abdul Halim Barkatullah, Politik Hukum Pidana (Kajian Kebijakan
Kriminalisasi dan Dekriminalisasi). Pustaka Pelajar. Jakarta. 2005.

Teuku Muhammad Radhie, Pembaharuan Dan Politik Hukum Dalam Rangka Pembangunan Nasional, dalam majalah prisma, nomor 6 tahun II, desember 1973.

Wirjono Prodjodikoro. Asas-Asas Hukum Pidana di Indonesia. PT. Refika Aditama. Bandung. 2008.

\section{Karya Ilmiah}

Lalu Parman. Prinsip individualisasi pidana dalam sistem pidana minimum khusus tindak pidana korupsi di Indonesia. (Disertasi Program Studi Doktor Ilmu Hukum Fakultas Hukum Universitas Brawijaya Malang, 2014).

Maulid Dina, Filosofi Penetapan Delik Perzinahan (Studi Komparasi Pasal 284 Kuhp Dan Fikih Jinayah, UIN Sunan Kalijaga Yogyakarta.

Mei Irma Mawadati. Implementasi Pemidanaan Terhadap Pelaku Tindak Pidana Perzinahan Oleh Hakim Pengadilan Negeri Surakarta. Universitas Sebelas Surakarta.

Pahrur Rizal. Makalah, Politik Hukum Pidana. Universitas Mataram. 2016.

\section{Peraturan Perundang-Undangan}

Kitab Undang-Undang Hukum Pidana (KUHP) Indonesia.

Undang-Undang Dasar (UUD) 1945.

Undang-undang Nomor 4 Tahun 2004 tentang Kebebasan Kekuasaan Kehakiman.

Undang-undang Nomor 1 Tahun 1974 Tenatang Perkawinan

\section{Internet}


Http://masrudim.blogspot.co.id

Kejaksaan Republik Indonesia, "Asasasas hukum pidana" dalam http://www.kejaksaan.go.id/pusdi klat/uplimg/File/Asasasas $\% 20$ Hukum\%20Pidana.doc (02 april 2017).

Lihat juga putusan MARI No. 30 /K/Kr/1969 dalam kasus jual beli vespa bekas, MARI NO. 72 $\mathrm{K} / \mathrm{Kr} / 1970$ dalam kasus penarikan cek kosong Caltex, MARI No. 43
K/Kr/1973, dalam kasus Komisi Dokter Hewan, MARI No. 97 K/Kr/1973 dalam kasus Deposito Telkom, MARI No. $81 \mathrm{~K} / \mathrm{Kr}$ /1973 dalam kasus Reboisasi Hutan.

http://www.kompasiana.com/luthfyavia $\mathrm{n} /$ problematika-asas-legalitasdalam-hukum-pidana-yangmempersempit-ruang-gerakhakim. 